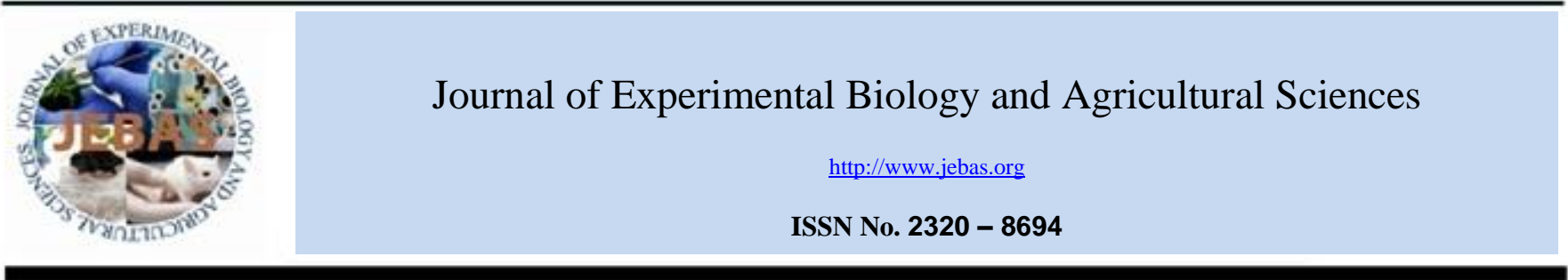

\title{
INDUCED GENETIC VARIABILITY IN SESAME (Sesamum indicum L): A COMPARATIVE STUDY ON THE MUTAGENIC EFFECTS OF RADIATION AND EMS IN SEED GERMINATION, POLLEN VIABILITY AND CHLOROPHYLL MUTANTS
}

\author{
Parthasarathi $\mathrm{G}^{1}$, Sugitha Thankappan ${ }^{2}$, M. Arumugam Pillai ${ }^{1}$ \\ R. Kannan ${ }^{4}$, S Merina Prem Kumari ${ }^{1}$, Asish K. Binodh ${ }^{3 *}$
}

\begin{abstract}
${ }^{1}$ Department of Plant Breeding and Genetics, Agricultural College and Research Institute, Killikulam, Vallanad, Tuticorin Dt -628252, Tamil Nadu, India
${ }^{2}$ School of Agriculture and Biosciences, Karunya Institute of Technology and Sciences, Coimbatore -641141, Tamil Nadu, India

${ }^{3}$ Centre for Plant Breeding and Genetics, Tamil Nadu Agricultural University, Coimbatore -641003, Tamil Nadu, India

${ }^{4}$ Department of Plant Pathology, Agricultural College and Research Institute, Killikulam, Vallanad, Tuticorin Dt -628252, Tamil Nadu, India
\end{abstract}

Received - September 09, 2020; Revision - November 10, 2020; Accepted - December 24, 2020

Available Online - December 30, 2020

DOI: http://dx.doi.org/10.18006/2020.8(6).774.788

KEYWORDS
Gamma rays
Ethyl Methane Sulphonate
(EMS)
LD $_{50}$
Sesame
Chlorophyll mutants
Mutagenic effectiveness

\begin{abstract}
The present study envisaged the effects of two mutagens, gamma rays and EMS on the phenotypes of two sesame varieties viz., TMV7 and SVPR1. A known quantity of dry, uniform, and healthy seeds of TMV7 and SVPR 1 were irradiated using $\mathrm{Co}^{60}$ (Cobalt 60) with different doses $(250,300,350,400,450 \mathrm{~Gy}$ ) of gamma rays. For chemical mutagenesis, different concentrations of EMS @ 0.20\%, 0.40\% and 0.60\% was used and treated for $8 \mathrm{~h}$. The dose-response curve of the probit analysis showed that the optimal lethal dose for SVPR1was lower than TMV7. The expected $\mathrm{LD}_{50}$ values of gamma radiation for TMV 7 and SVPR1 were 403.91Gy and 343.84Gy, respectively. For EMS, the expected $\mathrm{LD}_{50}$ values are $0.525 \%$ and $0.276 \%$ for TMV7 and SVPR1 respectively. Germination and pollen fertility declined linearly with an increase in dose or concentration of the mutagens. Three classes of chlorophyll mutants viz., xantha, chlorine, and viridis in $\mathrm{M}_{2}$ generation reveals a dose dependent relationship between mutagens and frequency of chlorophyll mutants. Mutagenic effectiveness was higher at lower doses whereas mutagenic efficiency was observed higher at extremity doses in both the varieties. The overall considerations on $\mathrm{M}_{1}$ generation effects showed that SVPR1was highly sensitive to gamma rays and TMV7 produced more viable mutationsthan SVPR1. The current studies suggest gamma rays as an efficient mutagen to induce essential mutations in TMV7 for the further crop improvement program.
\end{abstract}

* Corresponding author

E-mail: asish@tnau.ac.in (Dr. Asish K. Binodh)

Peer review under responsibility of Journal of Experimental Biology and Agricultural Sciences.

Production and Hosting by Horizon Publisher India [HPI] (http://www.horizonpublisherindia.in/).

All rights reserved.
All the articles published by Journal of Experimental Biology and Agricultural Sciences are licensed under a Creative Commons Attribution-NonCommercial 4.0 International License Based on a work at www.jebas.org.

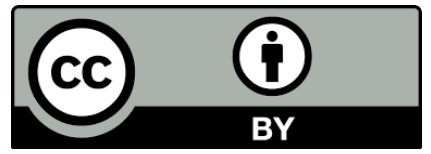




\section{Introduction}

Sesame (Sesamum indicum L.) the Indian olive oil is one of the world's important ancient oilseed crops known as "Queen of Oil seeds". Seeds are highly protein-rich and the essential amino acids particularly methionine are considered as rejuvenating and anti-aging factors (Namiki, 2007). Oil and protein content of sesame ranges from 48 to $55 \%$ and 20 to $28 \%$ respectively (Pathak et al., 2014). Fats in sesame oil are relatively stable and resist oxidative rancidity as compared to other oils. Sesame contains a high percentage of antioxidants such as sesamol, sesamin, sesamolin, and sesaminol; fatty acids like palmitic, stearic, oleic, and linoleic, and rich in minerals like vitamin E, calcium, magnesium, and phosphorus (Pusadkar et al., 2015; Myint et al., 2020). The sesame oil aids in reducing blood cholesterol, high blood pressure and prevents atherosclerosis, heart diseases, and cancers (Kumar \& Singh, 2015).

It is a self-pollinated annual shrub widely grown in tropical, subtropical, and temperate areas of the world, exceptionally in India, China, South America, and Africa (Tufail et al., 2020). The architecture of sesame is poorly adapted to modern farming owing to its indeterminate growth habit, non-uniform ripening of capsules, sensitivity to wilting under intensive management, and absence of non-shattering cultivars suited for mechanical harvest (Cagirgan, 2001). Lack of elite cultivars, with inherent resistance to biotic and abiotic stresses, leads to low productivity of sesame (0.33 tonnes $\mathrm{ha}^{-1}$ ) (Rao et al., 2017). Introgression of genes from wild relatives to cultivated varieties is largely unsuccessful due to the operation of high crossability barriers (Rajeswari et al., 2010; Chaudhary et al., 2019). To generate variability, attempts have been made by crossing to some extent, but desirable success could not have been attained.

Mutation breeding serves as an inevitable tool to rectify specific defects by creating desirable genetic variation with the help of physical or chemical mutagens (Chaudhary et al., 2019). Ionizing radiations include $\mathrm{X}$-rays, gamma rays, protons, neutrons, alpha, and beta particles. Gamma rays are widely employed for mutation studies due to their shorter wavelength and more penetration ability (Khin, 2006). Furthermore, chemical mutagens such as sodium azide, ethyl methane sulphonate (EMS), and N-ethyl-N-nitrosourea (ENU), shows distinct negative and positive impacts on the mutated populations (Mohd-Yusoff et al., 2015). EMS is a common mutagen for mutation breeding, that pairs with $\mathrm{T}$ instead of $\mathrm{C}$. The mispairing results in $\mathrm{G} / \mathrm{C}$ to $\mathrm{A} / \mathrm{T}$ transitions, apart from causing deletions and rearrangements (Rafi et al., 2016). Induced mutations with ionizing radiations and chemical mutagens offer desired phenotypic as well as genotypic effects, which can be further harnessed through recombination breeding or as such (Flibotte et al., 2010). Limited mutant population is advantageous in achieving genome-wide saturation mutagenesis (Henikoff \& Comai, 2003).
Mutagenic effectiveness and efficiency are two distinct properties of mutagens in plant breeding (Shah et al., 2008; Girija \& Dhanavel,2009). The product of maximum desirable changes associated with the least possible undesirable changes is termed efficient mutagenesis. These two criterions, viz., mutagenic efficiency and effectiveness of any mutagen, determines the success of a breeding scheme. Mutagenic efficiency is the rate of mutation produced to biological damage or injury by any mutagen. However, the efficacy of a mutagen is the rate of mutation produced relative to the dose of the mutagen (Anbarasan et al., 2015). Thus the choice of effective mutagen and dose to be used (preferably one that induces enormous variability in any crop) is highly crucial for untargeted induced mutagenesis. In general, the frequency of chlorophyll mutants is used for assessing the potency of any mutagen such as Albina, Striata, Chlorina, Xantha and Viridis.

Cultivated species of sesame is under the major threat of phyllody, caused by mycoplasma like organism. Recent studies highlighted that the area and production of sesame crop is declining in the traditional areas. Lack of resistant cultivars is one of the major constraints in sesame growing regions of India (Gupta et al., 2018). With an attempt to develop an improved sesame variety via induced mutagenesis, the present study deals with the mutagenic effectiveness and efficiency of two mutagens gamma ray (Physical mutagen) and ethyl methane sulphonate (chemical mutagen) in $\mathrm{M}_{2}$ generations of two commercial sesame varieties of Tamil Nadu, TMV7 and SVPR1.

\section{Materials and Methods}

The investigation was carried out at the experimental farm of plant breeding and Genetics, Agricultural College and Research Institute, Killikulam, Vallanad Tuticorin Dt, Tamil Nadu $\left(8^{\circ} 46\right.$ 'N latitude and $77^{\circ} 42^{\prime}$ E longitude) in two seasons Kharif (June Sept) and Rabi season (October - March) of 2019-20. The elevation of the site is $40 \mathrm{~m}$ above the mean sea level with relative humidity of 60 to $80 \%$, sub-tropical monsoon climate, and red lateritic soil (pH : 6.8; EC: $0.05 \mathrm{dSm}^{-1}$ ).

\subsection{Plant materials}

Seeds of two popular sesame cultivars TMV7 and SVPR1 were obtained from Oil seeds Research Station, Tindivanam, and Cotton Research Station, Srivilliputtur, Tamil Nadu Agricultural University (Table 1).

\subsection{Gamma irradiation}

A known quantity ( $2 \mathrm{~g}$ per dosage) of dry, uniform, and healthy seeds of two genotypes of sesame (TMV7 and SVPR 1) were irradiated using $\mathrm{Co}^{60}$ (Cobalt 60) gamma source with different doses (250, 300, $350,400,450 \mathrm{~Gy}$ ) of gamma rays at Indira Gandhi Centre for Atomic Research (IGCAR), Kalpakkam, Chennai, Tamil Nadu. The irradiated 
Table 1 Collection sites and typical characteristics of selected sesame cultivars

\begin{tabular}{|ccccc|}
\hline $\begin{array}{c}\text { Name of } \\
\text { Cultivar }\end{array}$ & Selected from & Seed coat color and surface & Days to maturity & 1000 Seed weight (g) \\
\hline TMV7 & $\begin{array}{c}\text { Oilseeds Research Station, } \\
\text { TindivanamTNAU }\end{array}$ & Brown, partially radially rough & $80-85$ & 3.15 \\
\hline SVPR1 & $\begin{array}{c}\text { Cotton Research Station, Srivilliputtur } \\
\text { TNAU }\end{array}$ & White, partially rough & $75-80$ & 3.05 \\
\hline
\end{tabular}

seeds were carefully transferred to sterile containers and sown in the experimental plot within $24 \mathrm{~h}$.

\subsection{Chemical Mutagenesis}

For EMS treatment, $2 \mathrm{~g}$ of dry, uniform, healthy, matured and viable seeds of the two varieties viz., TMV7 and SVPR1 were presoaked in distilled water for $12 \mathrm{~h}$ to enhance imbibing capacity. Pre-soaked seeds were treated in different concentrations of EMS, an alkylating chemical mutagen solution @ 0.20\%,0.40\%, and $0.60 \%$ for $8 \mathrm{~h}$ under controlled conditions at room temperature with intermittent shaking (Kim et al., 2006). After soaking, the treated seeds were washed in running water for an hour to remove the chemical residues. Sodium thiosulphate $(100 \mathrm{mM})$ was used to clean beakers and tips that can inactivate residual EMS and enables safe disposal.

\subsection{Lethal dose of gamma and EMS}

The $\mathrm{LD}_{50}$ values for gamma rays and EMS for both the genotypes were calculated according to the probit analysis (Finney, 1978). The probit function represents the inverse cumulative distribution function or quantile function associated with the standard normal distribution. The steps for probit analysis are (i) transformation of the dose concentration of mutagens into $\log _{10}$ values (ii) determination of the mortality $\%$ due to treatment doses. The proportions were corrected for control mortality if it is more than 10\% using Abbot Formula (Ramchander et al., 2015).

Corrected mortality $(\mathrm{p})=\frac{\% \text { responded }-\% \text { responded in control }}{100 \text { - responded in control }} \times 100$

The corrected proportions (p) were converted to empirical probits (y) and a dose-response regression curve drawn using $\log _{10}$ doses (x) and empirical probits (y). Empirical probits (y) values $<1$ and $>7$ are ignored (Hayes \& Kruger, 2014).

Empirical probits $(\mathrm{y})=5+(x-\mu) / s$

From equation (2) the expected probits (Yi) were derived. Chisquare values were obtained from the original mortality (Observed) and derived mortality (Expected). The non-significant Chi-square test indicates good curve fitting. The LD or LC values are derived from the curve drawn using probits and log doses. Antilog to the $\log _{10}$ value corresponds to respective probit value and $95 \%$ fiducial confidence limits are calculated using the formula

Fiducial Limits $=$ Antilog $\left(\log _{10}\right.$ Dose $\left.\pm 1.96(\mathrm{SE})\right)$

\subsection{Field Experiment}

Irradiated seeds $\left(\mathrm{M}_{0}\right)$ along with the controls (non-irradiated) were sown in the field in a randomized block design with three replications keeping plant to plant and row to row distance of 10 and $30 \mathrm{~cm}$, respectively during Kharif 2019 . Four to five capsules of each $\mathrm{M}_{1}$ plants against all the treatments were collected separately to raise the $\mathrm{M}_{2}$ generation. Individual plant to progeny rows was maintained in $\mathrm{M}_{2}$ generation (Rabi2019-'20) keeping row to row and plant to plant distance at $30 \mathrm{~cm}$ and $10 \mathrm{~cm}$, respectively. Immediately after germination, various types of chlorophyll mutants (albina, chlorina, xantha) were recorded to study the mutagenic effect of different doses. In every generation, other agronomic package, practices, and plant protection measures were taken throughout the experiment.

\subsection{Crop phenotyping}

Biological damage was measured in $\mathrm{M}_{1}$ generation in terms of total number of seeds germinated on 15 DAS, lethality (\% survival) reduction in seedling height (injury) of seedling in each treated population on 30 DAS and pollen sterility. In $\mathrm{M}_{2}$ generation, seedlings were screened from 10 to $20 \mathrm{DAS}$, to record various types of chlorophyll mutants periodically.

\subsubsection{Growth analysis}

For growth studies, percent germination of seeds observed on 15 DAS in each treated population. Seedling survival was recorded based on the total number of seedlings survived on 30 DAS and the survival percentage calculated as the ratio between numbers of plants survived to that of the number of seeds sown.

\subsubsection{Pollen sterility}

Randomly selected flowers from 10 plants were collected, and with the help of a needle and forceps, flowers dissected and anthers were taken out. Pollen grains were smeared in the glass slide of a compound microscope using $0.5 \%$ potassium iodide (KI) solution (Baker \& Baker, 1979) and counted for five microscopic fields. Regularly shaped and stained pollen grains were considered as fertile, whereas the unstained and empty ones as sterile. 


\subsubsection{Chlorophyll mutants}

Chlorophyll mutants were recorded in the $\mathrm{M}_{2}$ generation. The spectrum of chlorophyll mutants were characterized according to Gustafsson (1940) and Blixt (1961) as follows: Xantha- yellow to whitish yellow coloured leaves and it also has minimum survival up to 15 to 20 DAS. Chlorina- the presence of light green coloured seedlings and did not survive 15 days after sowing. Viridis - light green colour in the early stages of growth which gradually changed to the normal green colour during the subsequent period of growth and plants are viable.

\subsection{Efficiency and effectiveness of mutagens}

Mutagenic efficiency and effectiveness were recorded for each treatment according to the formula proposed by Anbarasan et al. (2013). The frequency of chlorophyll mutants were calculated as a percentage of segregating progenies and that of mutant seedlings in the $\mathrm{M}_{2}$ generation (Anbarasan et al., 2015).

$\begin{aligned} \text { Mutagenic effectiveness }= & \begin{array}{l}\text { Mutation Frequency } / \text { Dose or } \\ (\text { Concentration }(\mathrm{c}) \times \text { time }(\mathrm{t}))\end{array} \\ \text { Mutagenic efficiency }= & \text { Mutation Frequency } / \text { Biological damage } \\ \text { Mutagenic efficiency }= & \mathrm{M} \times 100 / \mathrm{L} \\ & \mathrm{M} \times 100 / \mathrm{I} \\ & \mathrm{M} \times 100 / \mathrm{S}\end{aligned}$

Where,

$M=$ Mutation frequency, $L=$ Percentage of lethality or survival reduction, $I=$ Percentage of injury or reduction in seedling size, $S$ $=$ Percentage of pollen sterility.

Sum of values of efficiency or

Mutation rate $=\frac{\text { effectiveness of particular mutagen }}{\text { Number of treatments of a particular mutagen }}$

\section{Results}

\subsection{Effect of mutagens on seed germination}

The percentage of seed germination decreased progressively as the doses/ concentrations of mutagens increased as compared with their respective controls. The germination response for gamma rays treated seeds ranged from $80.0 \%$ (250 Gy) to $40.0 \%$ (450 Gy) for TMV7 and from $72.5 \%$ (250 Gy) to $37.5 \%$ (450 Gy) for SVPR 1, whereas EMS treated seeds registered, $72.5 \%$ to $47.5 \%$ and $57.25 \%$ to $32.5 \%$ for TMV7 and SVPR1 respectively. Significant reduction in germination percent was exhibited by both gamma (86.49 to $43.24 \%$ ) and EMS (78.38 to $51.35 \%$ ) treated TMV 7 seeds over their corresponding controls. Furthermore, the percent reduction in the germination of gamma treated SVPR 1 was almost at par with TMV 7 whereas the EMS treated SVPR 1 showed deviation from 69.39 to $39.39 \%$ over control. However, the highest percentage of reduction in seed germination was observed at 450 Gy $(48.65 \%)$ followed by EMS treatment at $0.60 \%(56.76 \%)$ in
TMV7 and SVPR1 (54.55\% and 60.61\% respectively (Table 2 and Figure 1).

Furthermore, the seedling survival of both genotypes reduced significantly upon exposure to gamma rays and EMS as compared to respective controls (Table 2). On 30 DAS, SVPR1 displayed more sensitivity than TMV7 at $450 \mathrm{~Gy}$. The survival percent over control for EMS treated seedlings ranged between 7.03 to $22.46 \%$ for TMV7 and 7.8 to $10.9 \%$ for SVPR at various EMS concentrations.

The results of the seedling height indicates that TMV7 (43.33) was less affected by 450 Gy while the attribute was markedly affected in SVPR1 (32.10) as compared to control. On the contrary, TMV 7 showed more sensitivity to EMS than SVPR1. The seedling height progressively decreased in both genotypes with increasing EMS concentration. Among the genotypes, SVPR showed maximum reduction in seedling height $(67.90 \%)$ followed by TMV7 (56.67 $\%)$ at 450 Gy (Table 2 and Table S1).

\subsection{Lethal Dose $\left(L D_{50}\right)$ of mutagens}

Probit analysis was carried out using seed mortality rates in both the varieties for gamma rays and EMS to determine the Lethal Dose $\left(\mathrm{LD}_{50}\right)$. The optimal lethal dose was recorded at $0.276 \%$ and $0.525 \%$ for SVPR1and TMV7 to EMS respectively. In case of gamma irradiation, 343.843 Gy for SVPR1 and TMV7 fixed at 403.910 Gy (Table S2). The best fit dose-response curve of the probit analysis was shown in Figure 2. The results indicated that the optimal lethal dose for $S$. indicum var. SVPR1was lower than $S$. indicum var. TMV 7 in both the mutagens studied.

\subsection{Effect of mutagens on pollen sterility}

Percent increase in pollen sterility of TMV ranged from $15.5 \%$ ( $250 \mathrm{~Gy}$ ) to $55.67 \%$ (450 Gy) while in SVPR1 it ranged between $34.23 \%$ (250 Gy) to $64.03 \%$ (450 Gy). Similarly in EMS treatment, pollen sterility followed a linear increase from 6.98 $(0.20 \%)$ to $35.89(0.60 \%)$ for TMV7 while in SVPR1, an uptrend from $11.42(0.20 \%)$ to $37.96(0.605 \%)$. The effect of mutagens on pollen fertility was presented in Figures 3 and 4.

\subsection{Effect of induced mutagenesis on the spectrum of chlorophyll mutants}

Results of the current investigation showed a considerable increase in the spectrum of chlorophyll mutants such as xantha, chlorina, and viridis (Figure 5 and 6). Mutagenic frequency in inducing chlorophyll mutations by gamma rays ranged from $1.71(250 \mathrm{~Gy})$ to 2.81(450 Gy) for TMV7, while in SVPR1, the parameter ranged from 1.80 (250 Gy) to 3.03(450 Gy). For EMS, chlorophyll mutants were observed in the range of $1.36(0.20 \%)$ to $3.45(0.60 \%)$ and $1.33(0.20 \%)$ to $1.59(0.60 \%)$ for TMV7 and SVPR1 respectively. 
Table 2 Effect of mutagens on seed germination, seedling survival and seedling height of sesame varieties

\begin{tabular}{|c|c|c|c|c|c|c|c|c|}
\hline \multirow{2}{*}{\multicolumn{3}{|c|}{$\begin{array}{l}\text { Doses / Concentrations of } \\
\text { mutagens }\end{array}$}} & \multicolumn{2}{|c|}{ Seed germination (15 DAS) } & \multicolumn{2}{|c|}{ Seedling survival (30 DAS) } & \multicolumn{2}{|c|}{ Seedling height (30 DAS) } \\
\hline & & & $\begin{array}{c}\text { Mean } \pm \text { SE } \\
(\%)\end{array}$ & $\begin{array}{l}\text { Per cent over } \\
\text { control }\end{array}$ & $\begin{array}{c}\text { Mean } \pm \text { SE } \\
(\%)\end{array}$ & $\begin{array}{l}\text { Per cent over } \\
\text { control }\end{array}$ & $\begin{array}{c}\text { Mean } \pm \mathrm{SE} \\
(\%)\end{array}$ & $\begin{array}{c}\text { Per cent over } \\
\text { control }\end{array}$ \\
\hline \multirow{12}{*}{ 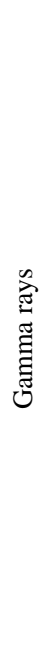 } & \multirow{6}{*}{$\sum_{i}^{N}$} & Control & $92.5 \pm 0.3^{\mathrm{a}}$ & 100.00 & $92.5 \pm 0.3^{\mathrm{a}}$ & 100.00 & $23.48 \pm 0.6^{\mathrm{a}}$ & 100.00 \\
\hline & & $250 \mathrm{~Gy}$ & $80.0 \pm 3.7^{c}$ & 86.49 & $20.0 \pm 2.2^{\mathrm{g}}$ & 21.62 & $18.11 \pm 0.4^{\mathrm{c}}$ & 77.12 \\
\hline & & $300 \mathrm{~Gy}$ & $77.5 \pm 2.5^{\mathrm{d}}$ & 83.78 & $27.5 \pm 3.7^{\mathrm{c}}$ & 29.73 & $16.53 \pm 0.2^{d}$ & 70.37 \\
\hline & & $350 \mathrm{~Gy}$ & $65.0 \pm 4.8^{\mathrm{f}}$ & 70.27 & $27.0 \pm 1.0^{\mathrm{d}}$ & 29.19 & $13.2 \pm 0.4^{\mathrm{f}}$ & 56.21 \\
\hline & & 400 Gy & $47.5 \pm 1.7^{\mathrm{h}}$ & 51.35 & $21.0 \pm 1.8^{\mathrm{f}}$ & 22.70 & $10.63 \pm 0.6^{\mathrm{h}}$ & 45.25 \\
\hline & & 450 Gy & $40.0 \pm 5.0^{\mathrm{j}}$ & 43.24 & $10.5 \pm 2.1^{\mathrm{j}}$ & 11.35 & $10.18 \pm 0.8^{\mathrm{i}}$ & 43.33 \\
\hline & \multirow{6}{*}{$\frac{\bar{n}}{\tilde{n}}$} & Control & $82.5 \pm 0.1^{b}$ & 100.00 & $82.5 \pm 0.1^{b}$ & 100.00 & $19.0 \pm 0.6^{\mathrm{b}}$ & 100.00 \\
\hline & & $250 \mathrm{~Gy}$ & $72.5 \pm 3.5^{\mathrm{e}}$ & 87.88 & $19.5 \pm 1.5^{\mathrm{f}}$ & 23.64 & $14.27 \pm 0.3^{\mathrm{e}}$ & 75.10 \\
\hline & & 300 Gy & $57.5 \pm 2.4^{\mathrm{g}}$ & 69.70 & $16.0 \pm 1.2^{\mathrm{i}}$ & 19.39 & $12.49 \pm 0.2^{\mathrm{g}}$ & 65.72 \\
\hline & & $350 \mathrm{~Gy}$ & $42.5 \pm 2.5^{\mathrm{i}}$ & 51.52 & $26.5 \pm 0.9^{\mathrm{e}}$ & 32.12 & $9.93 \pm 0.6^{j}$ & 52.28 \\
\hline & & $400 \mathrm{~Gy}$ & $40.0 \pm 4.8^{j}$ & 48.48 & $10.0 \pm 1.0^{\mathrm{k}}$ & 12.12 & $8.70 \pm 1.0^{\mathrm{k}}$ & 45.78 \\
\hline & & 450 Gy & $37.5 \pm 2.5^{\mathrm{k}}$ & 45.45 & $4.00 \pm 1.6^{1}$ & 4.85 & $6.10 \pm 0.3^{1}$ & 32.10 \\
\hline \multirow{8}{*}{$\sum_{\text {II }}^{\infty}$} & \multirow{4}{*}{$\sum_{i}^{N}$} & Control & $92.5 \pm 0.3^{\mathrm{a}}$ & 100.00 & $92.5 \pm 0.3^{\mathrm{a}}$ & 100.00 & $23.48 \pm 0.6^{\mathrm{a}}$ & 100.00 \\
\hline & & $0.2 \%$ & $72.5 \pm 5.5^{c}$ & 78.38 & $17.0 \pm 6.0^{\mathrm{d}}$ & 18.38 & $18.55 \pm 0.9^{d}$ & 78.99 \\
\hline & & $0.4 \%$ & $57.5 \pm 0.5^{\mathrm{d}}$ & 62.16 & $6.50 \pm 1.5^{\mathrm{g}}$ & 7.03 & $17.75 \pm 0.7^{\mathrm{e}}$ & 75.59 \\
\hline & & $0.6 \%$ & $47.5 \pm 7.9^{f}$ & 51.35 & $23.0 \pm 1.7^{\mathrm{c}}$ & 24.86 & $16.32 \pm 0.9^{g}$ & 69.52 \\
\hline & \multirow{4}{*}{$\frac{\vec{a}}{\vec{a}}$} & Control & $82.5 \pm 0.1^{\mathrm{b}}$ & 100.00 & $82.5 \pm 0.1^{b}$ & 100.00 & $19.0 \pm 0.6^{b}$ & 100.00 \\
\hline & & $0.2 \%$ & $57.2 \pm 0.1^{\mathrm{de}}$ & 69.39 & $9.0 \pm 0.1^{\mathrm{e}}$ & 10.91 & $18.84 \pm 1.1^{\mathrm{c}}$ & 98.74 \\
\hline & & $0.4 \%$ & $42.5 \pm 2.1^{\mathrm{g}}$ & 51.52 & $6.5 \pm 0.1^{g}$ & 7.88 & $17.37 \pm 0.5^{f}$ & 91.04 \\
\hline & & $0.6 \%$ & $32.5 \pm 1.0^{\mathrm{h}}$ & 39.39 & $8.0 \pm 1.0^{\mathrm{f}}$ & 9.70 & $15.77 \pm 0.3^{\mathrm{h}}$ & 82.63 \\
\hline
\end{tabular}

Data represented are mean \pm SE values of 3 replications and the experiment repeated thrice. Mean values followed by different small case letters with in columns are significantly different at $\mathrm{P} \leq 0.05$ level by Duncan's multiple range test. DMRT was applied to each mutagen separately.

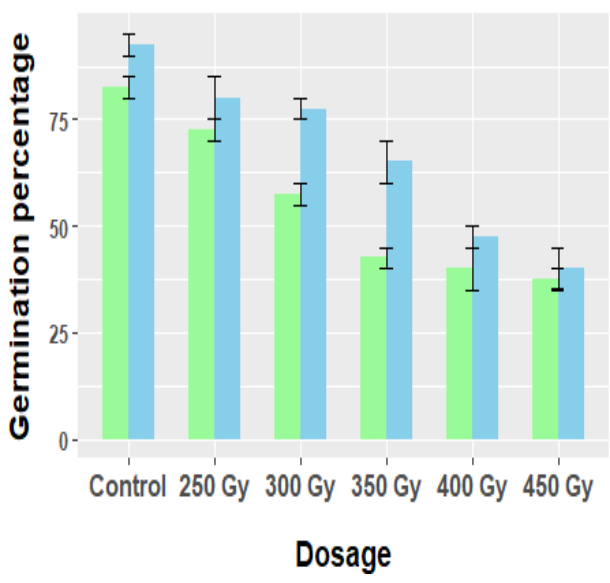

(A)

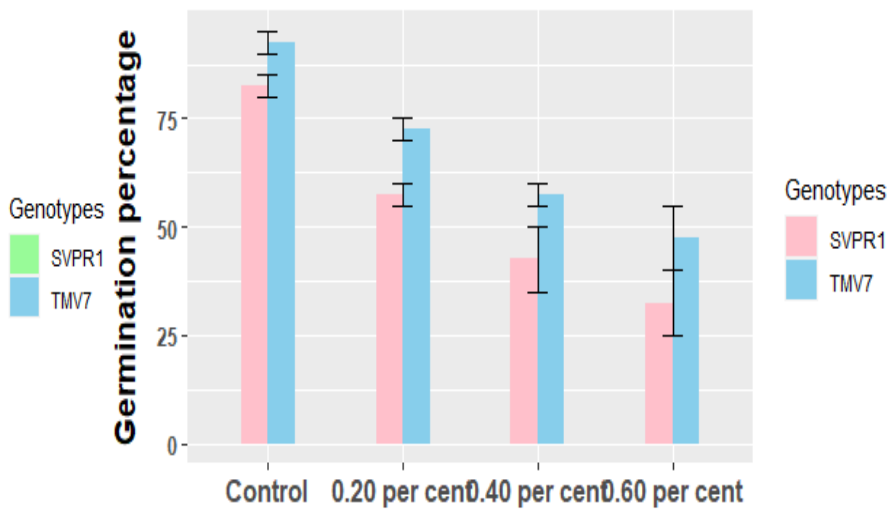

Dosage

(B)

Figure 1 Effect of mutagens on the germination per cent of sesame varieties SVPR1 and TMV 7. A) response to gamma rays B) response to EMS (Values represented are mean of three replications and the vertical bars indicate SE) 


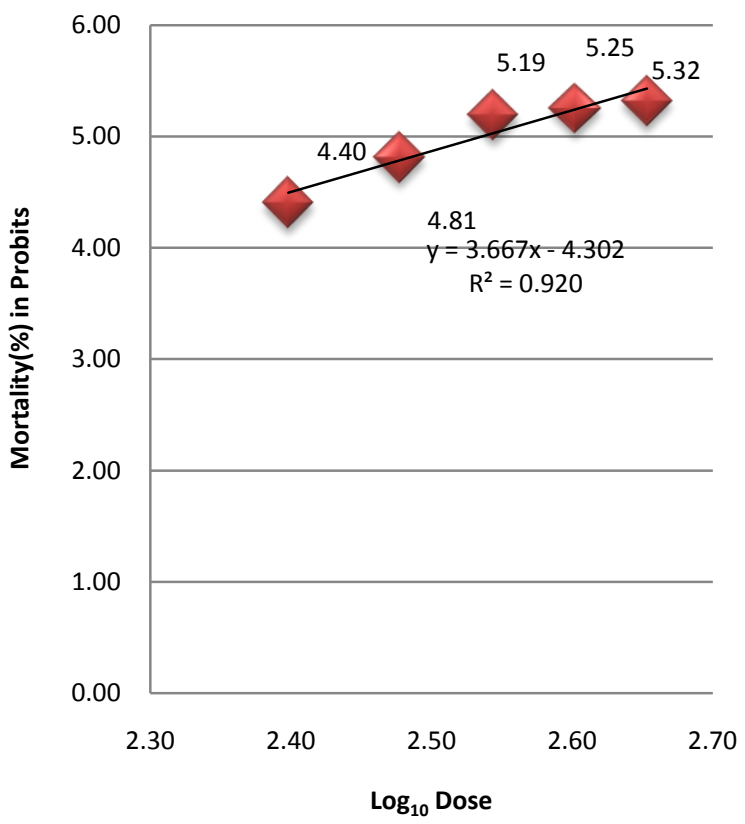

(A)

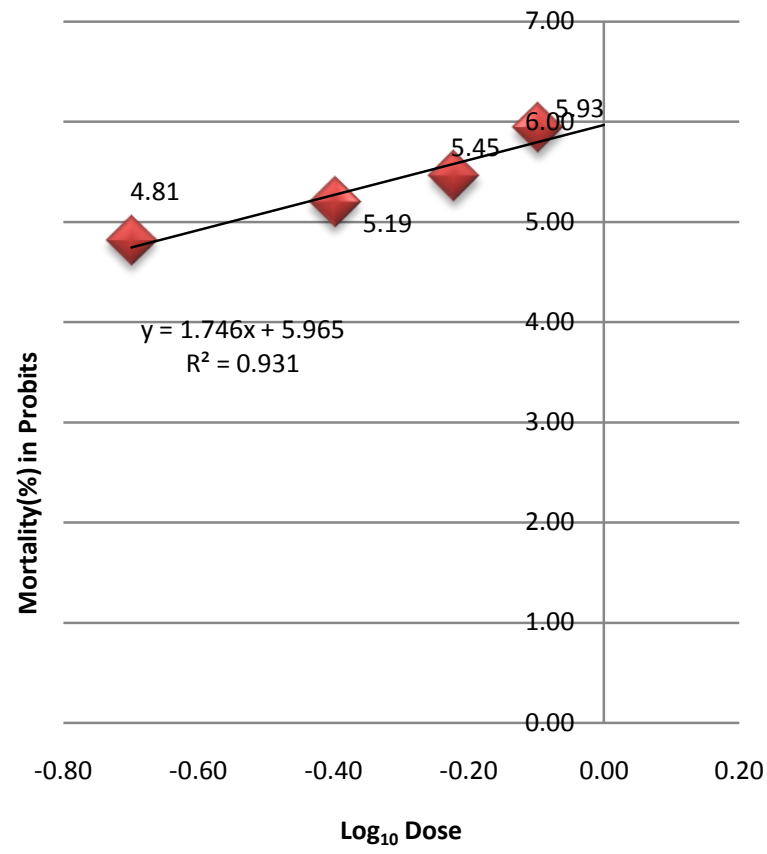

(C)

Figure 2 Dose response curve of Gamma ray irradiation of SVPR1 (A), TMV7 (B) and EMS treatment of SVPR1 (C) and TMV7 (D) derived by probit analysis. $R^{2}$ value $>0.9$ denotes best fit of the equation

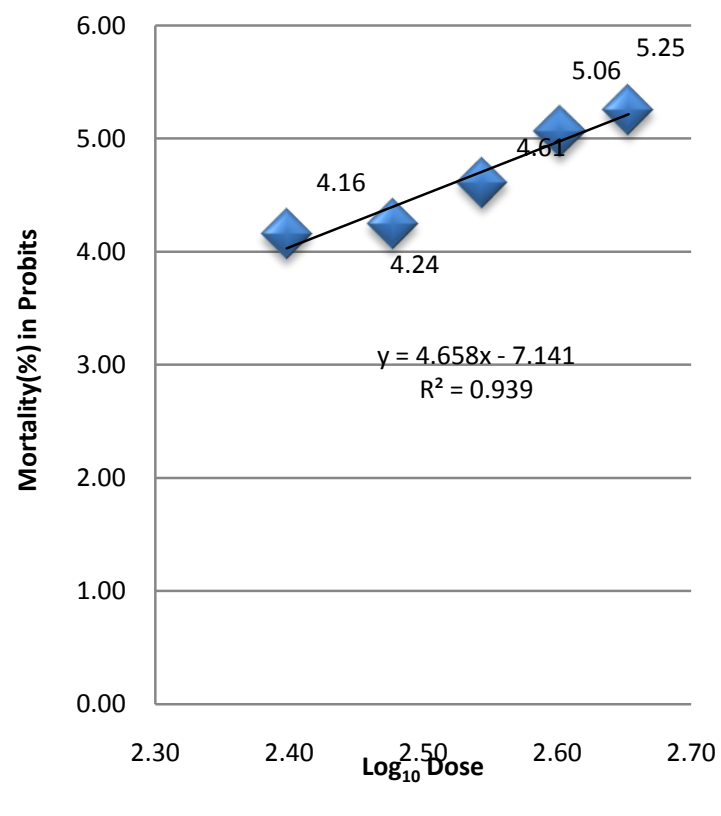

(B)

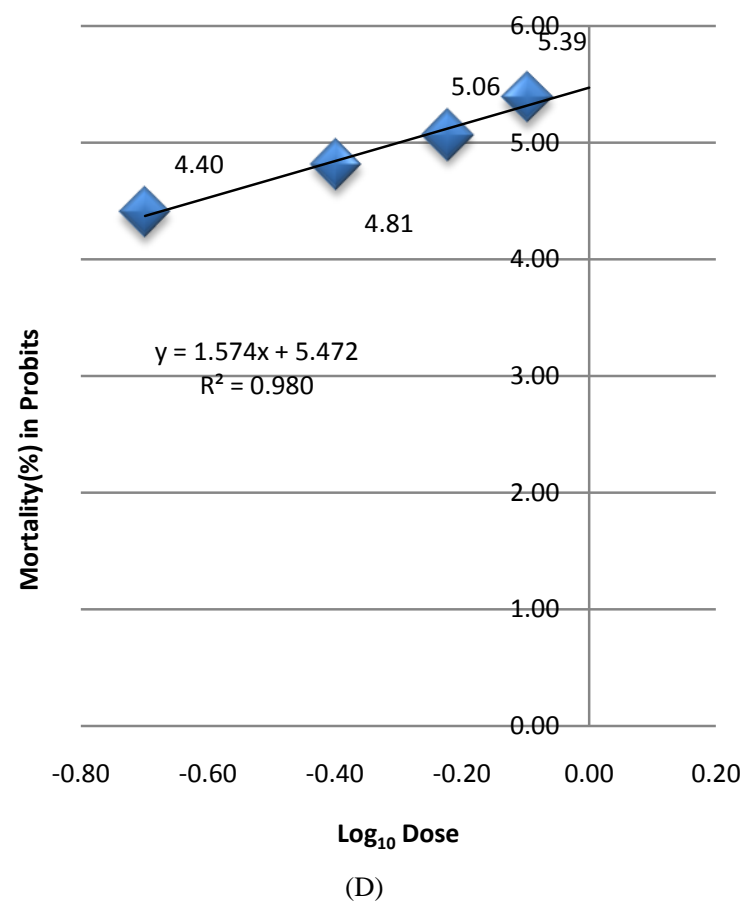


TMV7
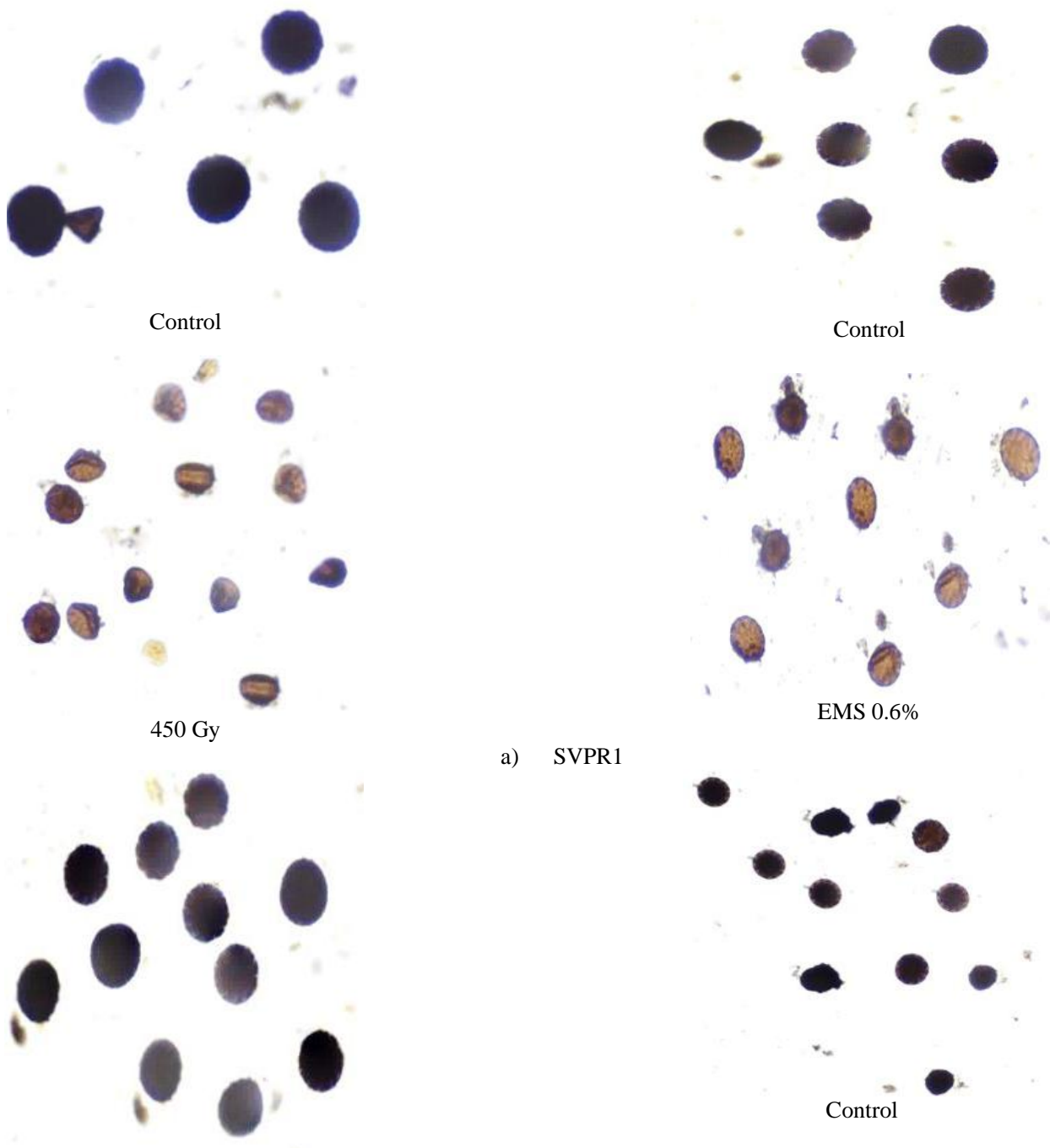

EMS $0.6 \%$

a) SVPR1

Control
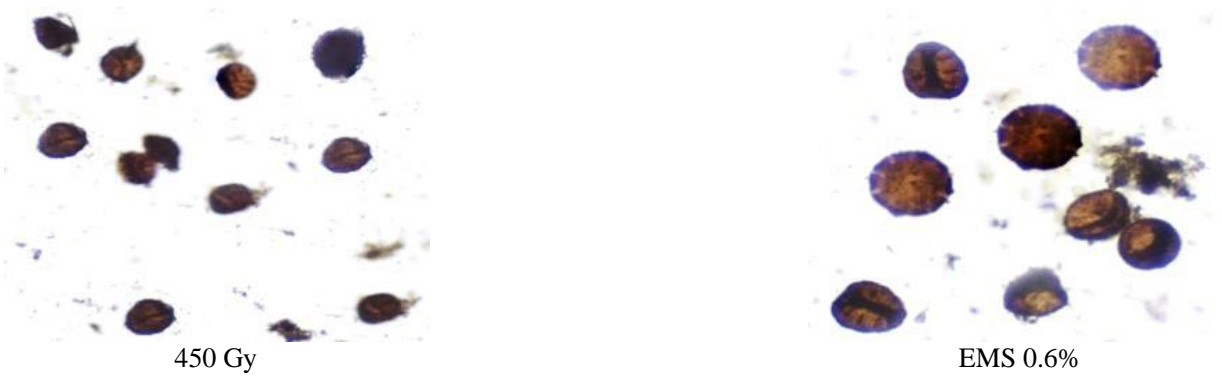

Figure 3 Microscopic images of pollen showing sterility in two sesame varieties affected by mutagens (Pollen grains were smeared in the glass slide of a compound microscope using $0.5 \%$ potassium iodide (KI) solution and counted for five microscopic field as per Baker \& Baker, 1979).

Journal of Experimental Biology and Agricultural Sciences http://www.jebas.org 


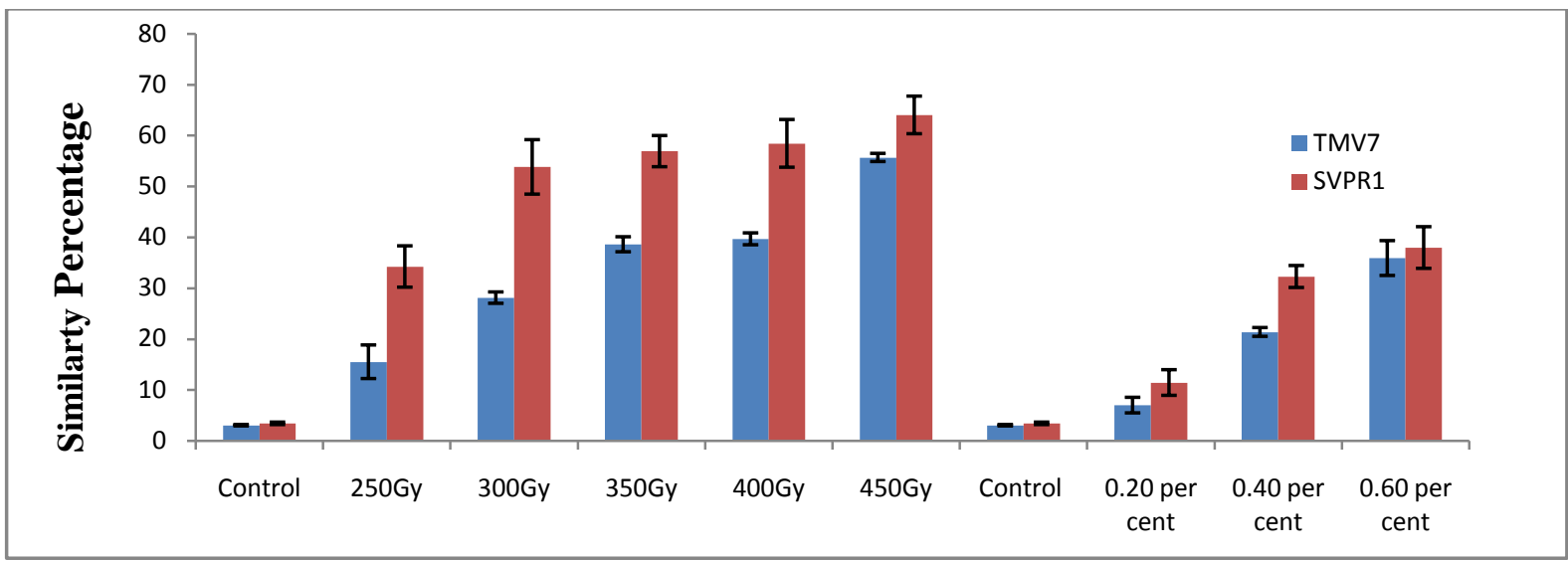

Figure 4 Effect of mutagens on reduction of pollen viability (Data represented are mean \pm SE from 3 replications and vertical bar represents corresponding SE).

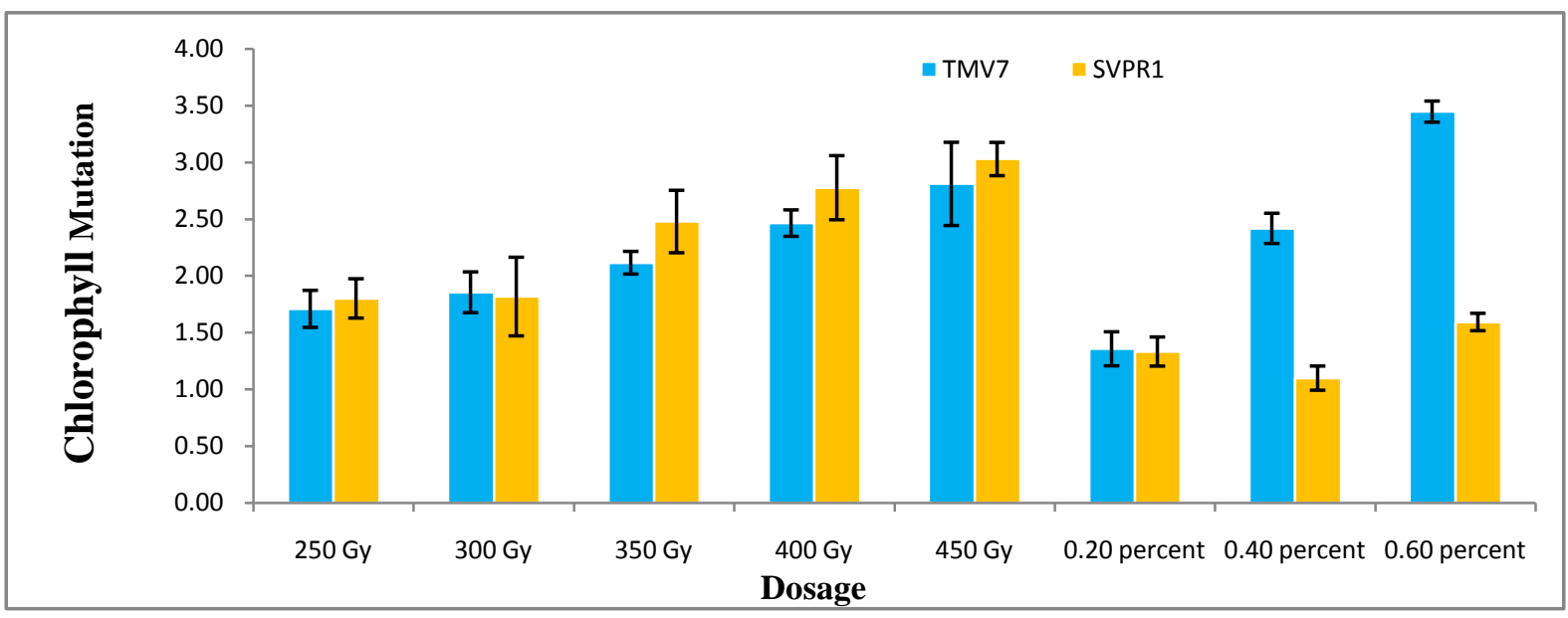

Figure 5 Chlorophyll mutation frequencies of two sesame varieties in response to gamma rays and EMS (Data represented are mean values of three replications and vertical bars indicates SE)
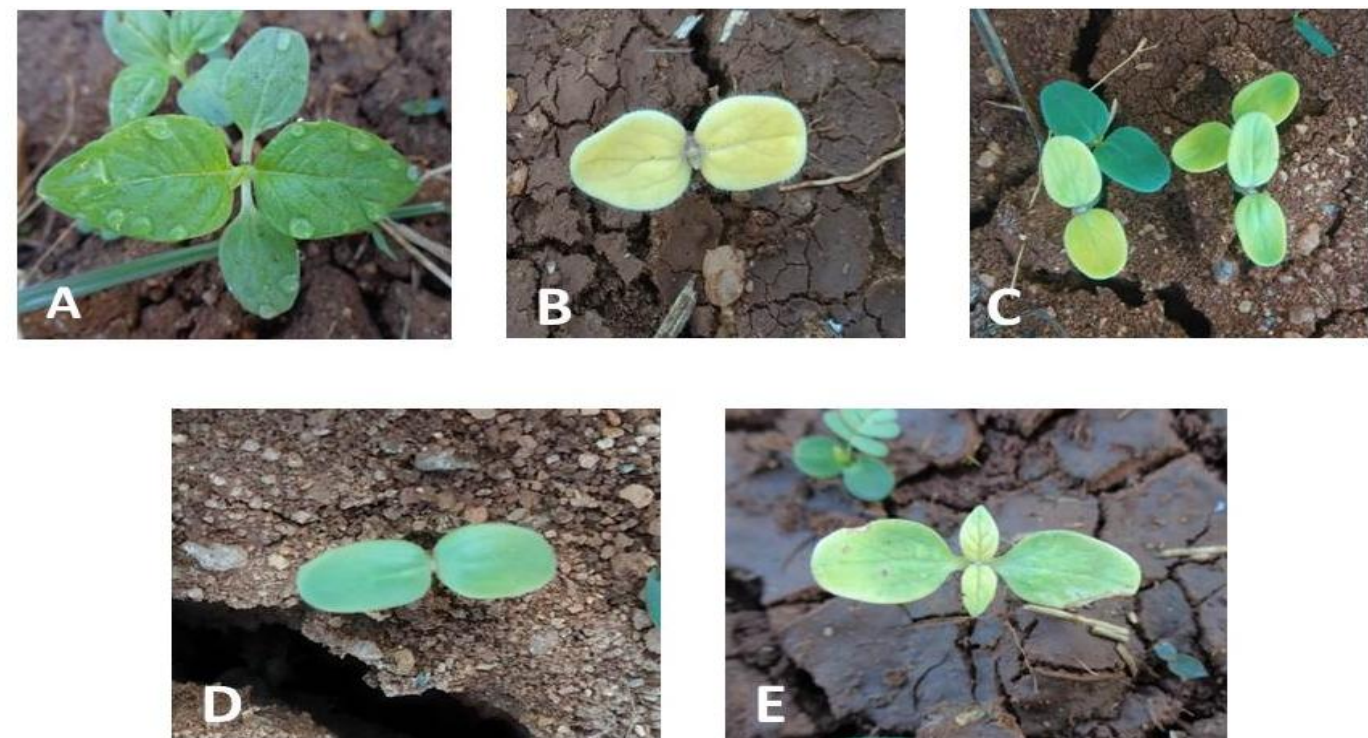

Figure 6 Chlorophyll mutants observed in $\mathrm{M}_{2}$ generation, A: control, B: xantha, $\mathrm{C}$ and $\mathrm{D}:$ chlorina, E: viridis

Journal of Experimental Biology and Agricultural Sciences http://www.jebas.org 

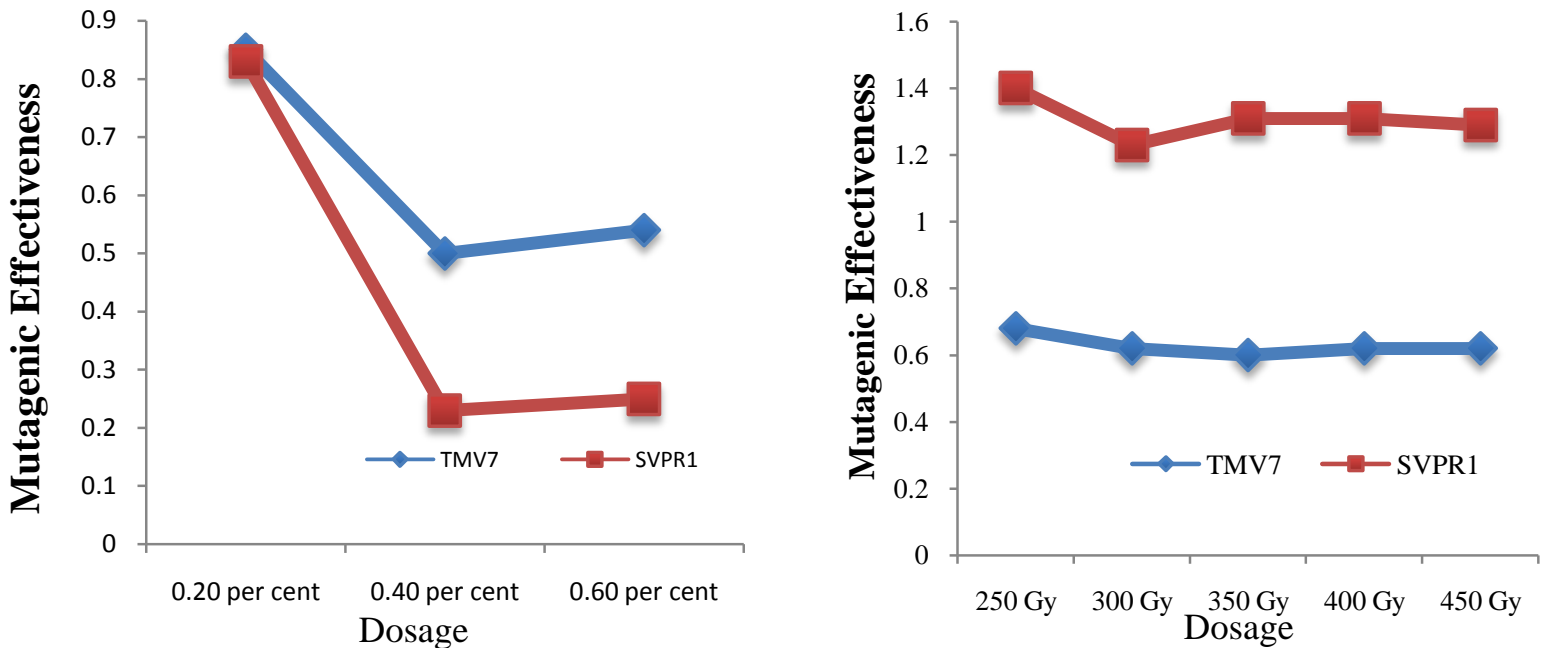

Figure 7 Line Diagram showing the mutagenic effectiveness of gamma ray (a) and EMS (b) in two sesame varieties (Values are mean of three replications)
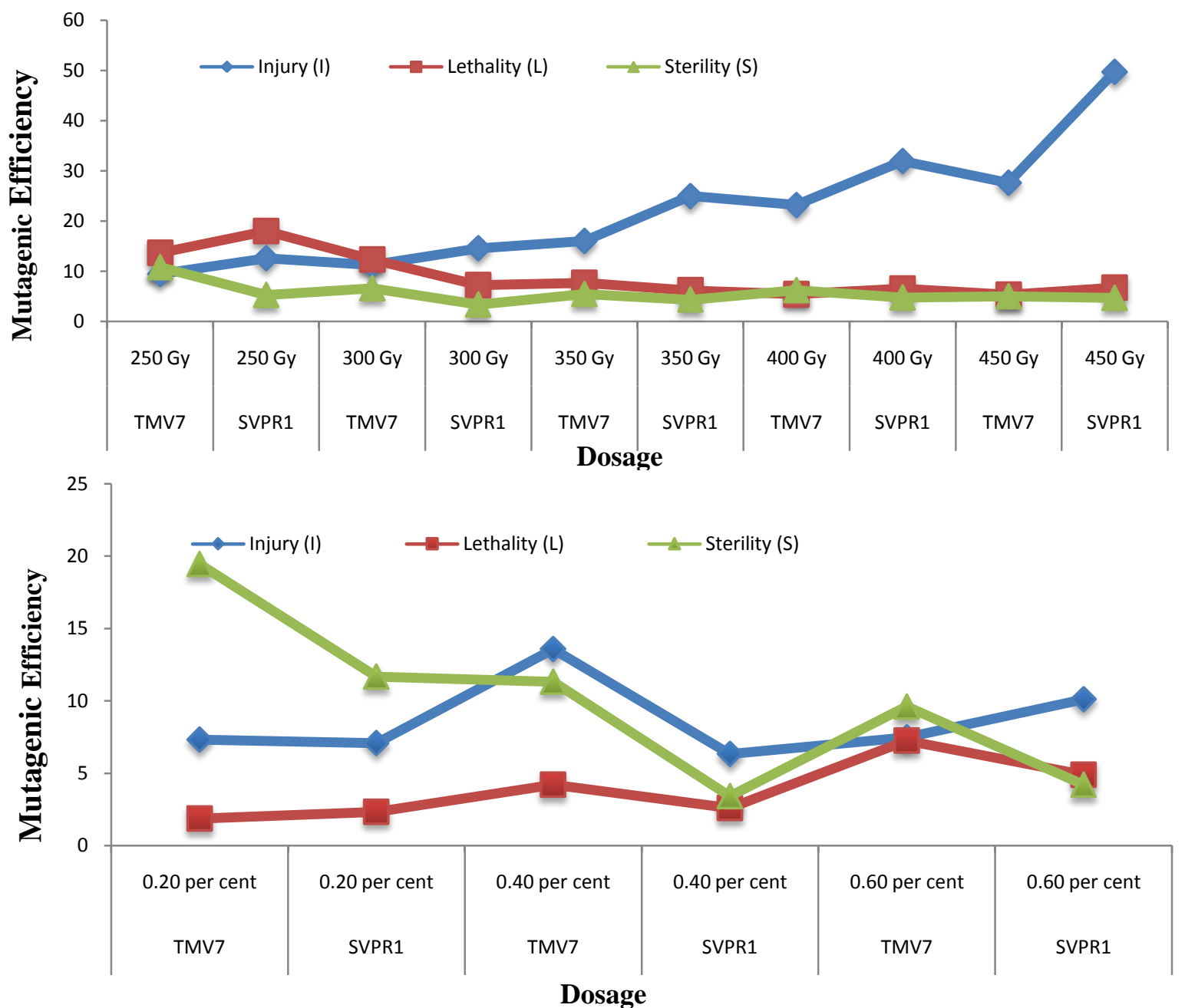

Figure 8 Line Diagram showing the mutagenic efficiencies of gamma ray (a) and EMS

(b) in two sesame varieties (Values are mean of three replications)

Journal of Experimental Biology and Agricultural Sciences http://www.jebas.org 
For gamma rays, the variety, TMV7 exhibited chlorophyll mutant frequency of xantha (6.42), chlorina (1.91), and viridis (2.64) while in SVPR1 $5.74 \%, 5.41 \%$, and $0.76 \%$ of xantha, chlorina, and viridis were recorded respectively (Table 3). Likewise EMS treated seeds of TMV 7 and SVPR1 showed $1.53 \%, 1.07 \%, 1.61 \%$ and $2.79 \%, 1.79 \%, 2.65 \%$ of xantha, chlorina and viridis respectively (Tables 3 and 4).

\subsection{Mutagenic effectiveness and efficiency}

Mutagenic effectiveness for gamma rays augmented between 0.68 (250 Gy) to 0.62 (450 Gy) for TMV7, while SVPR1 showed 0.72 (250 Gy) to 0.67 (250 Gy). On the contrary, EMS treatment registered mutagenic effectiveness of 0.85 to 0.54 and 0.83 to 0.25 for TMV7 and SVPR1 respectively (Figure 7 and 8).

Table 3: Frequency and spectrum of gamma ray induced chlorophyll mutants in $\mathrm{M}_{2}$ Generation

\begin{tabular}{|c|c|c|c|c|c|c|c|c|c|}
\hline \multirow{2}{*}{$\begin{array}{c}\text { Mutagen } \\
\text { Gamma } \\
\text { Rays } \\
\text { (Dosage) }\end{array}$} & \multicolumn{3}{|c|}{ Classes of chlorophyll mutants } & \multirow{2}{*}{$\begin{array}{l}\text { Number of } \\
\text { chlorophyll } \\
\text { mutants }\end{array}$} & \multirow{2}{*}{$\begin{array}{l}\text { Number of } \\
\text { plants } \\
\text { observed }\end{array}$} & \multicolumn{3}{|c|}{$\begin{array}{l}\text { Relative percentage (frequency) of } \\
\text { chlorophyll mutants }\end{array}$} & \multirow{2}{*}{$\begin{array}{l}\text { Mutagenic } \\
\text { Frequency }\end{array}$} \\
\hline & Xantha & Chlorina & Viridis & & & Xantha & Chlorina & Viridis & \\
\hline \multicolumn{10}{|c|}{ TMV7 } \\
\hline Control & 0 & 0 & 0 & 0 & 200 & 0.00 & 0.00 & 0.00 & 0 \\
\hline $250 \mathrm{~Gy}$ & 1 & 0 & 1 & 2 & 117 & 0.85 & 0.00 & 0.85 & 1.71 \\
\hline 300 Gy & 6 & 1 & 2 & 9 & 485 & 1.24 & 0.21 & 0.41 & 1.86 \\
\hline 350 Gy & 5 & 5 & 2 & 12 & 567 & 0.88 & 0.88 & 0.35 & 2.12 \\
\hline 400 Gy & 8 & 4 & 4 & 16 & 649 & 1.23 & 0.62 & 0.62 & 2.47 \\
\hline $450 \mathrm{~Gy}$ & 11 & 1 & 2 & 14 & 498 & 2.21 & 0.20 & 0.40 & 2.81 \\
\hline Total & & & & & & 6.42 & 1.91 & 2.64 & 10.96 \\
\hline \multicolumn{10}{|c|}{ SVPR1 } \\
\hline Control & 0 & 0 & 0 & 0 & 200 & 0.00 & 0.00 & 0.00 & 0 \\
\hline $250 \mathrm{~Gy}$ & 1 & 1 & 0 & 2 & 111 & 0.90 & 0.90 & 0.00 & 1.80 \\
\hline $300 \mathrm{~Gy}$ & 0 & 2 & 0 & 2 & 110 & 0.00 & 1.82 & 0.00 & 1.82 \\
\hline $350 \mathrm{~Gy}$ & 2 & 1 & 0 & 3 & 121 & 1.65 & 0.83 & 0.00 & 2.48 \\
\hline $400 \mathrm{~Gy}$ & 3 & 2 & 0 & 5 & 180 & 1.67 & 1.11 & 0.00 & 2.78 \\
\hline $450 \mathrm{~Gy}$ & 2 & 1 & 1 & 4 & 132 & 1.52 & 0.76 & 0.76 & 3.03 \\
\hline Total & & & & & & 5.74 & 5.41 & 0.76 & 11.91 \\
\hline
\end{tabular}

Data represented are mean values of 3 replications and the sampling size is 200 plants replication ${ }^{-1}$.

Table 4: Frequency and spectrum of EMS induced chlorophyll mutants in $\mathrm{M}_{2}$ generation

\begin{tabular}{|c|c|c|c|c|c|c|c|c|c|}
\hline \multirow{2}{*}{ EMS } & \multicolumn{3}{|c|}{$\begin{array}{l}\text { Classes of chlorophyll } \\
\text { mutants }\end{array}$} & \multirow{2}{*}{$\begin{array}{l}\text { Number of } \\
\text { chlorophyll } \\
\text { mutants }\end{array}$} & \multirow{2}{*}{$\begin{array}{c}\text { Number of } \\
\text { plants } \\
\text { observed }\end{array}$} & \multicolumn{3}{|c|}{$\begin{array}{l}\text { Relative percentage (frequency) of } \\
\text { chlorophyll mutants }\end{array}$} & \multirow{2}{*}{$\begin{array}{l}\text { Mutagenic } \\
\text { Frequency }\end{array}$} \\
\hline & Xantha & Chlorina & Viridis| & & & Xantha & Chlorina & Viridis & \\
\hline \multicolumn{10}{|c|}{ TMV7 } \\
\hline Control & 0 & 0 & 0 & 0 & 200 & 0.00 & 0.00 & 0.00 & 0 \\
\hline $0.20 \%$ & 2 & 0 & 1 & 3 & 221 & 0.90 & 0.00 & 0.45 & 1.36 \\
\hline $0.40 \%$ & 1 & 2 & 3 & 6 & 248 & 0.40 & 0.81 & 1.21 & 2.42 \\
\hline $0.60 \%$ & 3 & 2 & 2 & 7 & 203 & 1.48 & 0.99 & 0.99 & 3.45 \\
\hline Total & & & & & & 2.79 & 1.79 & 2.65 & 7.23 \\
\hline \multicolumn{10}{|c|}{ SVPR1 } \\
\hline Control & 0 & 0 & 0 & 0 & 200 & 0.00 & 0.00 & 0.00 & 0 \\
\hline $0.20 \%$ & 0 & 1 & 1 & 2 & 150 & 0.00 & 0.67 & 0.67 & 1.33 \\
\hline $0.40 \%$ & 1 & 0 & 1 & 2 & 182 & 0.55 & 0.00 & 0.55 & 1.10 \\
\hline $0.60 \%$ & 2 & 1 & 1 & 4 & 251 & 0.80 & 0.40 & 0.40 & 1.59 \\
\hline Total & & & & & & 1.35 & 1.07 & 1.61 & 4.03 \\
\hline
\end{tabular}

Data represented are mean values of 3 replications and the sampling size is 200 plants replication ${ }^{-1}$. 
Mutagenic efficiency in terms of injury registered a considerable variation among the mutants studied. The results implied that gamma rays displayed $87.52 \%$ (TMV7) to $133.76 \%$ (SVPR1) whereas, EMS showed $28.39 \%$ (TMV7) to $23.51 \%$ (SVPR1) efficiency. In terms of lethality, TMV7 and SVPR1 exhibited 13.68 and 9.82\% for EMS and 44.57 (TMV7) and 44.74 (SVPR1) for gamma rays. Significant sterility was observed in TMV (40.38) and SVPR1 (19.28) exposed to EMS followed by gamma rays ( 34.16 and 22.48 respectively).

\section{Discussion}

Induced mutagenesis is one of the tools to create genetic and phenotypic variability in plants with a higher frequency than spontaneous mutations (Chopra, 2005). Artificially induced mutations are employed using physical or chemical mutagens in which $\mathrm{LD}_{50}$ values have been considered as a critical factor for efficient mutations (Anbarasan et al., 2013). The lethal dose indicates the lethal toxicity of a given substance or type of radiation. Besides, the resistance varies from one individual to another, the "lethal dose" represents a dose at which a given percentage of plants will die. In the present investigation, the $\mathrm{LD}_{50}$ was calculated based on seed germination at different doses of gamma rays and EMS. Mean germination percentage of $S$. indicum (Var. TMV $7 \&$ SVPR1) genotypes at 5 different doses of gamma rays and 3 different doses of EMS was recorded. The $\mathrm{LD}_{50}$ was calculated based on percent germination on 15 DAS. The seedlings having normal roots and shoots were considered for calculating the $\mathrm{LD}_{50}$ as most of the seedlings from delayed germinated seeds were abnormal. The $\mathrm{LD}_{50}$ for the $S$. indicum var. SVPR1 was found nearly $14.87 \%$ lower than the $\mathrm{LD}_{50}$ of the genotypes of $S$. indicum var. TMV 7 in gamma rays treatment. Similarly

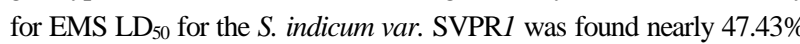
lower than the $\mathrm{LD}_{50}$ of the genotypes of $S$. indicum var. TMV 7. More specifically, the optimal lethal dose for $S$. indicum var. SVPR1 was much lower than S. indicum var. TMV 7 in both the mutagens studied. The variation in the $\mathrm{LD}_{50}$ of the two varieties for both physical and EMS of the same species was found different, suggesting that it may vary from one genotype to another. It might be due to the differences in their genetic constitution and their parentage. The differential response of genotypes among the same species was reported by Sandhiya et al. (2020) on sesame varieties SVPR1 and VRI3 to EMS treatment and in the rice varieties white ponni and BPT 5204 to gamma radiation by Ramchander et al. (2015).

The biological damage caused by gamma rays and EMS in M generation can be estimated based on plant survival (Ramchander et al. 2015). Likewise, the results indicated that the germination percentage decreased progressively as the doses/ concentrations of mutagens increased. The percent germination of gamma treated TMV 7 was reduced from 86.49 to 43.24 and EMS was treated from 78.38 to 51.35 respectively. The highest percentage of reduction in seed germination was observed at EMS treatment at higher doses $(0.60 \%)$ in TMV7 (47.5\%) followed by $450 \mathrm{~Gy}$ in TMV7 (40\%) and SVPR1 (37.5\%).
Among the genotypes, SVPR1 was found to be more sensitive than TMV7. Besides, the results revealed that the doses of EMS higher than $1 \%$ are highly lethal irrespective of genotype and species. The seedling survival on 30 days after treatment (DAT) was found to have a similar trend as of germination percentage. Most of the seedlings that emerged from delayed germinated seeds were abnormal which could not develop into normal seedlings. The results illustrated the effect of mutagenic treatment on the germination of seeds and their lethality. In all the mutagenic treatments, a significant reduction in seedling survival (lethality) and seedling height (injury) were observed. Similar works were done by various researchers (Anbarasan et al., 2013; Anbarasan et al., 2015; Kumari et al., 2016a; Ariharasutharsan et al., 2019; Sandhiya et al., 2020) on various sesame genotypes and observed a dose dependent reduction in germination percentage. The results are in agreement with Akilan et al. (2020) and Ramchander et al. (2015) in rice, Vasko \& Kyrychenko (2019) in sunflower and Olorunmaiye et al. (2019) in groundnut.

Induced mutagenesis affects mitotic index or increases micronuclei number and pollen abnormalities (Savaskan \& Atila, 1991). The present investigation envisaged a significant impact of dose response on pollen fertility. In general, SVPR1 was sensitive to both the mutagens for pollen fertility. However, a gradual reduction in pollen fertility percentage was observed with an increase in the dose of mutagens. The above results are in agreement with earlier works of Pradhan \& Paul (2019b) in sesame and Manjunath et al. (2020) in groundnut. Reciprocally percentage of sterile pollen grains increased significantly and observed high at extreme dose ranges. In gamma rays, pollen sterility percentage increased from $34.23 \%$ to $64.03 \%$ and $15.5 \%$ to $55.67 \%$ for SVPR1 and TMV7 respectively. But in the case of EMS mutagenesis, a gradual increase in pollen sterility was observed than that of gamma rays in both the varieties. Pollen sterility of mutagens is the result of chromosomal aberrations, damage in the synthesis of genetic material (DNA or RNA) that leads to meiotic abnormalities (Ramchander et al., 2015). EMS owes its biological activity via the transfer of ethyl group by SNI (substitution, nucleophilic, unimolecular) or SN2 (substitution, nucleophilic, and bimolecular) (Rafi et al., 2016)

Chlorophyll mutation helps in assessing the effectiveness and efficiency of a mutagen to produce a desirable genetic variation with the least undesirable effects. Accordingly, the spectrum of chlorophyll mutants like chlorina, viridis, albino, and xantha were observed in individual treatments. Chlorophyll mutant displayed a deficit of chlorophyll in primary leaves which occurs up to 15 DAS (Stummann \& Henningsen, 1980). Due to recessive nature, chlorophyll mutant appears in $\mathbf{M}_{2}$ generation and not in $\mathrm{M}_{1}$ generation. In the present study, Albino and Striata type of chlorophyll mutations were absent in both Gamma-ray and EMS treated seeds of TMV7 and SVPR1. The current study recorded the highest frequency of Xantha $(6.42 \& 5.74)$ in gamma rays treated seeds irrespective of varieties, TMV7 and SVPR1 respectively. Similarly, EMS treatment also exhibited the highest frequency of Xantha 
(2.79) in TMV7 and Viridis (1.61) in SVPR1. At $0.60 \%$ concentration maximum frequency of Xantha (1.48 \& 0.80) found in TMV7 and SVPR1 respectively. The maximum frequency of Xantha mutants was scored in gamma ray than EMS treatment which supports the work of Tamilzharasi et al. (2019). Among the three classes of mutants, frequency of Chlorina (1.79 \& 1.07) was found least in EMS treatment of TMV7 and SVPR1 respectively. According to Ramadoss et al. (2014), the frequency of chlorophyll mutants was low in oil seed crops owing to their resistance to induced chlorophyll mutations. The total mutagenic frequency was found to be higher at $0.60 \%$ concentration of EMS (3.45 \& 1.59) treatment of TMV7 and SVPR1 respectively. However, the present study advocates that the mutagenic frequency of chlorophyl mutant of gamma ray treatments was higher than EMS treatments of both the varieties. The results are in agreement with earlier reports by (Boureima et al., 2012; Anbarasan et al., 2015; Kumari et al., 2016b; Pradhan \& Paul, 2019a). Gene mutations in terms of dose and efficiency are represented as an estimate of induced biological effects viz., lethality, injury, and sterility. It is measured in terms of mutagenic effectiveness. According to Gaul (1972), to achieve high mutagenic efficiency, the mutagenic effect must surpass the cell damage. The current study indicated that mutagenic effectiveness (ME) was maximum $(0.68$ \& 0.72 ) at 250 Gy in both the varieties viz., TMV7 and SVPR1 respectively, while in EMS treatment, significant ME $(0.85 \& 0.83)$ was observed at $0.20 \%$ concentration in both the varieties viz., TMV7 and SVPR1 respectively. Among the mutagens, Gamma rays exhibited higher mutagenic effectiveness compared to EMS. However, the mutagenic effectiveness decreases with an increase in gamma rays strength irrespective of genotypes. Similar findings on the decrease in mutagenic effectiveness with increasing doses of gamma rays and EMS were reported in cowpea (Priyadharshni et al., 2020), and EMS in pigeonpea (Etther et al., 2019).

Likewise, the present study remarked that the mutagenic efficiency of gamma rays was higher in two different doses viz., 450 Gy for injury and

a)

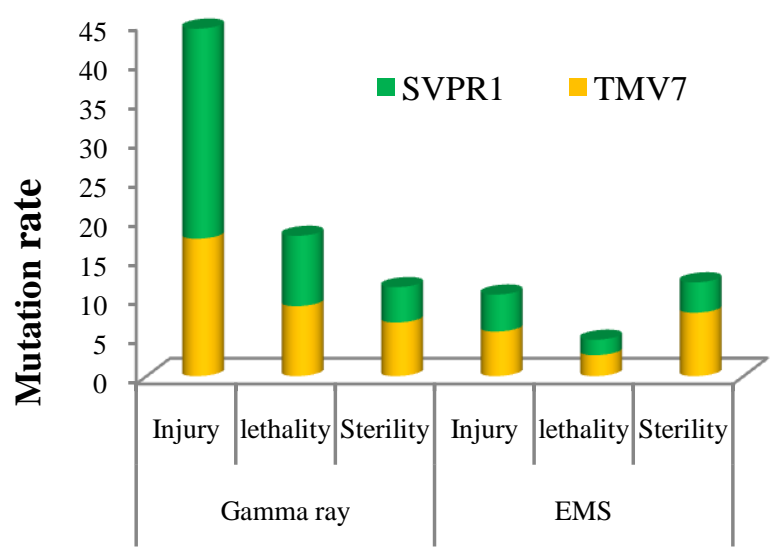

$250 \mathrm{~Gy}$ for lethality and sterility in both the varieties. However, the EMS treated TMV7 expressed higher mutagenic efficiency in all the three concentrations viz, $0.40 \%$ for injury (13.58) and $0.60 \%$ for lethality (7.26), and $0.20 \%$ for sterility (19.45). More interstingly it was noted that the mutagenic efficiency is proportional to the dose or strength of mutagens in two varieties of sesame studied. Contrastingly, a dose dependent decline in the efficiency was reported by Vinithashri et al. (2019). At higher doses of both the mutagens higher efficiency in terms of lethality was expressed which was not supporting the work of Majhi \& Mogali (2020). However, higher efficiency to sterility was observed at the highest concentration of EMS and the lowest dose in gamma rays.

Furthermore, the present study provided insights into the mutagenic efficiencies of two mutagens in two sesame varieties (Figure 9). The response of SVPR to gamma rays in terms of higher injury and lethality rate and TMV by inducing sterility was noted. More precisely, EMS induced TMV7 mutants exhibited more injury and lethality than SVPR1. Overall, SVPR1 is highly sensitive to both the mutagens. Furthermore, the present study also demonstrated that the degree of sensitivity differs with genotypes on subjecting to mutation (Pérez-Jiménez et al., 2020).

\section{Conclusions}

The present study concludes that lower doses or concentrations of mutagens are more effective and efficient than higher doses. SVPR1 was highly sensitive to gamma rays whereas, TMV7 produced more viable mutations. Gamma induced mutagenesis created diverse chlorophyll mutants xantha, chlorine, and viridis. The pollen fertility and plant growth showed a linear fashion of reduction with an increase in dosage of mutagens, in both the varieties. Gamma rays have proven to be a possible and more efficient mutagen to induce essential economic mutations in TMV 7.

Figure 9 Mutation rate in terms of effectiveness (a) and efficiency (b) in $\mathrm{M}_{2}$ generation of two sesame varieties.

Journal of Experimental Biology and Agricultural Sciences

http://www.jebas.org 


\section{Supplementary Material}

Table S1. Effect of mutagnes on per cent reduction of germination and growth (Supplementary data)

\begin{tabular}{|c|c|c|c|c|c|}
\hline \multicolumn{3}{|c|}{ Doses / Concentrations of mutagens } & $\begin{array}{l}\text { Seed germination } 15 \text { DAS } \\
\text { Per cent reduction over }\end{array}$ & $\begin{array}{l}\text { Seedling survival on } 30 \text { DAS } \\
\text { Per cent reduction over }\end{array}$ & $\begin{array}{l}\text { Seedling height on } 30 \text { DAS Per } \\
\text { cent reduction over control }\end{array}$ \\
\hline \multirow{12}{*}{ 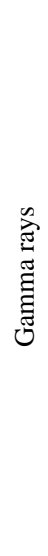 } & \multirow{6}{*}{$\sum_{i}^{i}$} & Control & 0.00 & 0.00 & 0.00 \\
\hline & & $250 \mathrm{~Gy}$ & -13.51 & -78.38 & -22.88 \\
\hline & & $300 \mathrm{~Gy}$ & -16.22 & -70.27 & -29.63 \\
\hline & & $350 \mathrm{~Gy}$ & -29.73 & -70.81 & -43.79 \\
\hline & & $400 \mathrm{~Gy}$ & -48.65 & -77.30 & -54.75 \\
\hline & & $450 \mathrm{~Gy}$ & -56.76 & -88.65 & -56.67 \\
\hline & \multirow{6}{*}{ 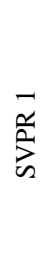 } & Control & 0.00 & 0.00 & 0.00 \\
\hline & & $250 \mathrm{~Gy}$ & -12.12 & -76.36 & -24.90 \\
\hline & & $300 \mathrm{~Gy}$ & -30.30 & -80.61 & -34.28 \\
\hline & & 350 Gy & -48.48 & -67.88 & -47.72 \\
\hline & & $400 \mathrm{~Gy}$ & -51.52 & -87.88 & -54.22 \\
\hline & & $450 \mathrm{~Gy}$ & -54.55 & -95.15 & -67.90 \\
\hline \multirow{8}{*}{$\sum_{I=1}^{\infty}$} & \multirow{4}{*}{$\sum_{i}^{i}$} & Control & 0.00 & 0.00 & 0.00 \\
\hline & & $0.20 \%$ & -21.62 & -81.62 & -21.01 \\
\hline & & $0.40 \%$ & -37.84 & -92.97 & -24.41 \\
\hline & & $0.60 \%$ & -48.65 & -75.14 & -30.48 \\
\hline & \multirow{4}{*}{$\frac{\bar{a}}{\tilde{a}}$} & Control & 0.00 & 0.00 & 0.00 \\
\hline & & $0.20 \%$ & -30.61 & -89.09 & -1.26 \\
\hline & & $0.40 \%$ & -48.48 & -92.12 & -8.96 \\
\hline & & $0.60 \%$ & -60.61 & -90.30 & -17.37 \\
\hline
\end{tabular}

Table $\mathrm{S} 2 \mathrm{LD}_{50}$ values of mutgaens EMS and gamma rays in sesame varieties (Supplementary data)

\begin{tabular}{|ccc|}
\hline Genotypes & EMS $(\%)$ & Gamma rays (Gy) \\
\hline SVPR1 & 0.276 & 343.843 \\
\hline TMV7 & 0.525 & 403.910 \\
\hline
\end{tabular}

\section{Declaration of competing interest}

The authors declare no conflict of interest

\section{Acknowledgment}

Authors are grateful to Indira Gandhi Centre for Atomic Research (IGCAR), Kalpakkam, Chennai, Tamil Nadu for providing necessary lab facilities for irradiating sesame varieties.

\section{References}

Gupta K, Naik K, Bisen R(2018) Status of sesame diseases and their integrated management using indigenous practices. International Journal of Chemical Studies 6:1945-1952.

Akilan M, Vanniarajan C, Subramanian E, Anandhi K, Anand G (2020) Sensitivity and Insensitivity of various traits to Mutagen treatment in rice (Oryza sativa L.). Journal of Experimental Biology and Agricultural Sciences 8: 381-389.
Anbarasan K, Rajendran R, Sivalingam D (2015) Studies on the Mutagenic Effectiveness and Efficiency of Gamma Rays, EMS and Combined Treatment in Sesame (Sesamum indicum L.) var. TMV3. Research Journal of Pharmaceutical Biological and Chemical Sciences 6: 589-595.

Anbarasan K, Sivalingam D, Rajendran R, Anbazhagan M, Chidambaram A (2013) Studies on the mutagenic effect of EMS on seed germination and seedling characters of Sesame (Sesamum indicum L.) Var. TMV3. International Journal of research in Biological sciences3: 68-70.

Ariharasutharsan G, Parameswari C, Vanniarajan C, Murugan E, Ramesh C (2019) Radio sensitivity studies in white seeded sesame (Sesamum indicum L.). Electronic Journal of Plant Breeding 10: 797-803. 
Baker HG, Baker I (1979) Starch in angiosperm pollen grains and its evolutionary significance. American Journal of Botany66: 591-600.

Blixt S (1961) Quantitative studies of induced mutations in peas. V. Chlorophyll mutations. Agri Hortique Genetica18: 219-227

Boureima S, Oukarroum A, Diouf M, Cisse N, Van Damme $\mathrm{P}(2012)$ Screening for drought tolerance in mutant germplasm of sesame (Sesamum indicum) probing by chlorophyll a fluorescence. Environmental and Experimental Botany 81: 37-43.

Cagirgan M (2001) Mutation techniques in sesame (Sesamum indicum L.) for intensive management: Confirmed mutants. No. IAEA-TECDOC-1195.

Chaudhary J, Alisha A, Bhatt V, Chandanshive S, Kumar N, Mi, Z, Kumar A, Yadav SK, Shivaraj SM, Sonah H, Deshmukh R (2019) Mutation breeding in tomato: advances, applicability and challenges. Plants 8: 128.

Chopra VL (2005) Mutagenesis: Investigating the process and processing the outcomes for crop improvement. Current Science 89: 353-359.

Etther Y, Gahukar SJ, Akhare A, Patil AN, Jambhulkar SJ, Gawande M (2019) Mutagenic effectiveness and efficiency of gamma rays, Ethyl methyl sulfonate and their synergistic effects in Pigeonpea (Cajanus cajan L.). Journal of Pharmacognosy and Phytochemistry 8: 489-93.

Finney DJ (1978) Statistical Method in Biological Assay. Charles Griffin \& Co.

Flibotte S, Edgley ML, Chaudhry I, Taylor J, Neil SE, Rogula A, Zapf R, Hirst M, Butterfield Y, Jones SJ, Marra MA (2010) Whole-genome sequencing profiling of mutagenesis in Caenorhabditis elegans. Genetics 185: 431-441.

Gaul H (1972) Mutations in plant breeding. Radiation Botany 4: 155-232.

Girija M, Dhanavel D (2009) Mutagenic effectiveness and efficiency of gamma rays, ethyl methane sulphonate and their combined treatments in cowpea (Vigna unguiculata L. Walp). Global Journal of Molecular Sciences4: 68-75.

Gustafsson A (1940) The mutation system of the chlorophyll apparatus. Lund University Arskr 36: 1-40.

Hayes AW, Kruger CL (Eds.) (2014) Handbook of Hayes' principles and methods of toxicology, $6^{\text {th }}$ Edition, CRC Press, Boca Raton, NY.

Henikoff S, Comai L (2003). Single-nucleotide mutations for plant functional genomics. Annual Review of Plant Biology 54: 375-401.

Khin T (2006) Rice mutation breeding for varietals improvement in Myanmar. Plant mutation reports 1: 34-36.

Kim Y, Schumake KS, Zhu JK (2006) EMS mutagenesis of Arabidopsis. In: Arabidopsis Protocols, Humana Press: 101-103.
Kumar CM, Singh SA (2015) Bioactive lignans from sesame (Sesamum indicum L.): evaluation of their antioxidant and antibacterial effects for food applications. Journal of Food Science and Technology 52: 2934-2941.

Kumari V, Chaudhary HK, Prasad R, Kumar A, Singh A, Jambhulkar S, Sanju S (2016a) Effect of Mutagenesis on Germination, Growth and Fertility in Sesame (Sesamum indicum L.). Annual Research \& Review in Biology16: 1-9.

Kumari V, Chaudhary HK, Prasad R, Kumar A, Singh A, Jambhulkar S, Sanju S (2016b) Frequency and Spectrum of Mutations induced by Gamma radiations and Ethyl methane sulphonate in Sesame (Sesamum indicum L.). Scientia Agriculturae 14: $270-278$.

Majhi PK, Mogali SC (2020) Studies on mutagenic effectiveness and efficiency of gamma rays in greengram [Vigna radiata (L.)Wilczek]. International Journal of Current Microbiology and Applied Sciences 9: 1475-1484.

Manjunath NG, Saravanan S, Sushmitha R, Pillai MA, Sheela J, Shoba D (2020) Mutagenic efficiency and effectiveness of gamma rays and EMS in groundnut (Arachis hypogaea L.). Electronic Journal of Plant Breeding 11: 875-80.

Mohd-Yusoff NF, Ruperao P, Tomoyoshi NE, Edwards D, Gresshoff PM, Biswas B, Batley J (2015) Scanning ethyl methanesulphonate effects on the whole genome of Lotus japonicus using second generation sequencing analysis. G3-Genes - Genomes- Genetics. 5: 559-567.

Myint D, Gilani SA, Kawase M, Watanabe KN (2020) Sustainable Sesame (Sesamum indicum L.) Production through Improved Technology: An Overview of Production, Challenges, and Opportunities in Myanmar. Sustainability 12: 3515.

Namiki M (2007) Nutraceutical functions of sesame: a review. Critical Reviews in Food Science and Nutrition 47: 651673.

Olorunmaiye KS, Joseph GG, Animasaun DA, Oyedeji S (2019) Mutagenic components and dosage effects of ethyl methanesulphonate on Arachis hypogea (Samnut 24 VR.). Ife Journal of Science 21: 309-22.

Pathak N, Rai A, Kumari R, Bhat K (2014) Value addition in sesame: A perspective on bioactive components for enhancing utility and profitability. Pharmacognosy Reviews 8: 147.

Pérez-Jiménez M, Tallón CI, Pérez-Tornero O (2020) Inducing mutations in Citrus spp.: Sensitivity of different sources of plant material to gamma radiation. Applied Radiation and Isotopes 157:109030

Pradhan M, Paul A (2019a) Spectrum and frequency of chlorophyll mutation in Sesame (Sesamum indicum). The Pharma Innovation International Journal 8: 453-455.

Pradhan M, Paul A Study on Radio Sensitivity of Gamma Rays on Different Genotypes of Sesame (Sesamum indicum). International 
Journal of Current Microbiology and Applied Sciences 8: 13341343.

Priyadharshni S, Saravanan S, Elanchezyan K, Pushpam AK, Pillai MA (2020) Efficiency and effectiveness of physical and chemical mutagens in cowpea (Vigna ungiculata (L.) Walp). Electronic Journal of Plant Breeding 11: 803-808.

Pusadkar P, Kokiladevi E, Bonde S, Mohite N (2015) Sesame (Sesamum indicum L.) importance and its high quality seed oil: a review. Trends in Biosciences 8: 3900-3906.

Rafi S, Kamili AN, Ganai B, Mir MY, Parray JA (2016) Morphobiochemical evaluation of EMS regenerated mutants of Bergenia ciliata(Haw.) Sternb. underin vitro conditions. Journal of Nature and Natural Sciences 1: 1-4.

Rajeswari S, Thiruvengadam V, Ramaswamy N (2010) Production of interspecific hybrids between Sesamum alatum Thonn and Sesamum indicum L. through ovule culture and screening for phyllody disease resistance. South African Journal of Botany 76: 252-258.

Ramadoss BR, Ganesamurthy K, Angapapn K, Gunasekaran M (2014) Mutagenic effectiveness and efficeincy of gamamrays in sesame (Sesamum indicum L.). Global Journal of Molecular Sciences 9: 01-06.

Ramchander S, Ushakumari R, Pillai MA (2015) Lethal dose fixation and sensitivity of rice varieties to gamma radiation. Indian Journal of Agricultural Research 49: 24-31.

Rao GP, Thorat V, Manimekalai R, Tiwari AK, Yadav A(2017) A century progress of research on phytoplasma diseases in India. Phytopathogenic Mollicutes 7: 1-38.
Sandhiya V, Kumar M, Parameswari C, Vanniarajan C, Kumaravadivel N, Sakthivel N, Badigannavar AM (2020) Determination of optimum dose of chemical mutagen for large scale seed treatment of white seeded sesame (Sesamum indicum L.) varieties. Electronic Journal of Plant Breeding 11: 238-42.

Savaskan C, Atilla A (1991) The effects of gamma irradiation on Gossypium hirsutum L. pollen. Turkish Journal of Nuclear Sciences 18: 39-45.

Shah TM, Mirza JI, Haq MA, Atta BM (2008) Induced genetic variability in chickpea (Cicer arietinum L.). II. Comparative mutagenic effectiveness and efficiency of physical and chemical mutagens. Pakistan Journal of Botany 40: 605-613.

Stummann BM, Henningsen KW (1980) Characterization of chlorophyll deficient mutants of pea. Hereditas 93: 261-275.

Tamilzharasi M, Kumaresan D, Souframanien J, Jayamani P (2019) Study of chlorophyll deficit types through induced mutagenesis in blackgram (Vigna mungo L. Hepper). Electronic Journal of Plant Breeding 10: 1471-1476.

Tufail T, Riaz M, Arshad MU, Gilani SA, Ain HBU, Khursheed T, Islam Z, Imran M, Bashir S, Shahid MZ, Kazmi SMU (2020) Functional and nutraceutical scenario of flaxseed and sesame: A. International Journal of Biosciences 17: 173-190.

Vasko VO, Kyrychenko VV (2019) Induced Mutagenesis for the Creation of New Starting Material in Sunflower Breeding. Helia 42: 17-36.

Vinithashri G, Manonmani S, Anand G, Meena S, Bhuvaneswari K, John Joel A, Vanniarajan C, Ganesamurthy K, Kumar V (2020) Mutagenic effectiveness and efficiency of sodium azide in rice varieties. Electronic Journal of Plant Breeding 11: 197-203. 